\title{
Peripartum cardiomyopathy: experience in an Asian tertiary centre
}

\author{
Choon Pin Lim ${ }^{1}$, MBBS, MRCP, David Kheng Leng $\underline{\operatorname{Sim}}^{1}$, MBBS, MRCP
}

INTRODUCTION Peripartum cardiomyopathy (PPCM) is a rare but life-threatening condition. We report 11 patients admitted to the National Heart Centre Singapore with a diagnosis of PPCM over a period of 14 months.

METHODS Baseline demographics, pregnancy history, haematology, serum biochemistry and echocardiographic findings of women admitted with a diagnosis of PPCM were analysed.

RESULTS The incidence of PPCM was 0.89 per 1,000 live births in our cohort. $63.6 \%$ of the patients were Malay and $27.3 \%$ were Chinese. $45.5 \%$ of the patients were smokers and $45.5 \%$ had a history of pregnancy-induced hypertension or preeclampsia. There was no maternal mortality. Mean left ventricular ejection fractions at diagnosis and at six months were $26.9 \% \pm 9.1 \%$ and $51.9 \% \pm 10.6 \%$, respectively. Mean left ventricular internal diameters in end-diastole at diagnosis and at six months were $5.5 \pm 0.5 \mathrm{~cm}$ and $5.1 \pm 0.6 \mathrm{~cm}$, respectively. All patients were treated successfully for the acute episode and all but one patient had returned to New York Heart Association functional class I status at six months.

CONCLUSION PPCM remains a rare condition and appears to occur more commonly in Malay patients. Smoking and pregnancy-induced hypertension appear to be significant risk factors. While short-term outcome remains excellent, collaborative studies with other tertiary centres will help enhance our understanding of the long-term management of and clinical outcomes in these patients.

Keywords: cardiomyopathy, heart failure, peripartum, pregnancy

Singapore Med J 2013; 54(1): 24-27

\section{INTRODUCTION}

Peripartum cardiomyopathy (PPCM) is a rare but life-threatening condition that may complicate a pregnancy. The mortality rate, previously reported to be $4 \%-80 \%$ in the 1980 s and 1990 s, has dropped steadily with advancements in modern therapy. ${ }^{(1-3)}$ We report 11 patients who presented with PPCM to the National Heart Centre Singapore over a period of 14 months.

\section{METHODS}

A retrospective analysis was performed on all patients admitted to our centre with a diagnosis of PPCM between October 2009 and November 2010. The diagnosis of PPCM was based on the following four criteria described by the National Heart, Lung and Blood Institute: (a) development of cardiac failure in the last month of pregnancy or within five months of delivery; (b) absence of an identifiable cause of cardiac failure; (c) absence of recognisable heart disease prior to the last month of pregnancy; and (d) left ventricular systolic dysfunction demonstrated by echocardiographic criteria such as depressed left ventricular ejection fraction (LVEF). ${ }^{(4)}$

Baseline demographics, pregnancy history, haematology, serum biochemistry and echocardiographic findings were analysed for all patients. These women were followed up in the heart failure outpatient clinic upon discharge. Echocardiographic findings and status at the six-month follow-up were described according to the New York Heart Association (NYHA) functional classification.

\section{RESULTS}

The incidence of PPCM in our study was 0.89 per 1,000 live births. The mean age of patients was $32.3 \pm 5.7$ years. There were seven (63.6\%) Malay, three (27.3\%) Chinese and one (9.1\%) Japanese women in the study group (Table I). Eight $(72.7 \%)$ women were in their first pregnancies, two were in their second pregnancies and one patient had delivered her fifth child. One patient had a twin pregnancy. $45.5 \%$ of the women were smokers, and $45.5 \%$ had a history of pregnancy-induced hypertension or preeclampsia. The mean white blood cell count was $15.6 \pm 5.1 \times 10^{9} / \mathrm{L}$ and the mean haemoglobin level was 10.8 $\pm 2.2 \mathrm{~g} / \mathrm{L}$ in our group. The mean serum creatinine was $71.8 \pm$ $21.3 \mu \mathrm{mol} / \mathrm{L}$, troponin T was $0.044 \pm 0.042 \mathrm{ug} / \mathrm{L}$ and $\mathrm{N}$-terminal prohormone of b-type natriuretic peptide (NT-proBNP) was $6,764 \pm 3,887 \mathrm{pg} / \mathrm{mL}$.

A majority of the patients $(72.8 \%)$ developed symptoms postpartum. In our cohort, symptoms presented two days before delivery to 55 days after delivery (mean 12.8 days postpartum). Six $(54.5 \%)$ patients presented with mild-to-moderate heart failure, while five (45.5\%) patients presented with frank acute pulmonary oedema. Four patients among the five with pulmonary oedema needed mechanical ventilation. Only one patient required intravenous dobutamine for inotropic support. All patients received conventional treatment with angiotensin-converting enzyme inhibitor (ACE-I) or angiotensin II receptor blockers (ARBs) and $\beta$-blockers, unless contraindicated. All 11 patients were successfully treated for the acute episode and discharged well.

\footnotetext{
${ }^{1}$ National Heart Centre Singapore, Singapore

Correspondence: $\operatorname{Dr}$ Choon Pin Lim, Associate Consultant, National Heart Centre Singapore, 17 Third Hospital Avenue, Singapore 168752. lim.choon.pin@nhcs.com.sg
} 
Table I. Clinical characteristics and outcomes of the patients diagnosed with peripartum cardiomyopathy $(n=11)$.

\begin{tabular}{|c|c|c|c|c|c|c|c|c|c|}
\hline \multirow{2}{*}{$\begin{array}{l}\text { Patient } \\
\text { no. }\end{array}$} & \multirow[t]{2}{*}{ Demographics } & \multirow{2}{*}{$\begin{array}{l}\text { Onset of } \\
\text { PPCM } \\
\text { post } \\
\text { delivery } \\
\text { (days) }\end{array}$} & \multirow{2}{*}{$\begin{array}{l}\text { Smoking } \\
\text { history }\end{array}$} & \multirow[t]{2}{*}{ Comorbidities } & \multirow{2}{*}{$\begin{array}{l}\text { Initial presentation/ } \\
\text { treatment }\end{array}$} & \multirow{2}{*}{$\begin{array}{l}\text { Mechanical } \\
\text { ventilation }\end{array}$} & \multicolumn{2}{|c|}{ Echocardiographic findings } & \multirow{2}{*}{$\begin{array}{l}\text { Functional } \\
\text { status at } \\
\text { six months }\end{array}$} \\
\hline & & & & & & & Initial & At six months & \\
\hline 1 & $\begin{array}{l}40 \text { yrs/ } \\
\text { Malay/ } \\
\text { G2P2 }\end{array}$ & 51 & No & $\mathrm{PIH}$ & $\begin{array}{l}\text { Mild CCF/IV diuretics, } \\
\beta \text {-blocker, ACE-I }\end{array}$ & No & $\begin{array}{l}\text { LVEF } 25 \% \text {, } \\
\text { LVIDd } 6.37 \mathrm{~cm} \text {, } \\
\text { moderate MR }\end{array}$ & $\begin{array}{l}\text { LVEF } 46 \% \text {, } \\
\text { LVIDd } 5.8 \mathrm{~cm} \text {, } \\
\text { trivial MR }\end{array}$ & NYHA I \\
\hline 2 & $\begin{array}{l}21 \text { yrs/ } \\
\text { Malay/ } \\
\text { G2P1 }\end{array}$ & 3 & Yes & NA & $\begin{array}{l}\text { APO requiring } \\
\text { mechanical } \\
\text { ventilation/ } \beta- \\
\text { blocker, ACE-I }\end{array}$ & Yes & $\begin{array}{l}\text { LVEF } 35 \% \text {, } \\
\text { LVIDd } 5.14 \mathrm{~cm} \text {, } \\
\text { no MR }\end{array}$ & $\begin{array}{l}\text { Lost to } \\
\text { follow-up }\end{array}$ & $\begin{array}{l}\text { Lost to } \\
\text { follow-up }\end{array}$ \\
\hline 3 & $\begin{array}{l}31 \text { yrs/ } \\
\text { Malay/ } \\
\text { G2P2 }\end{array}$ & -2 & Yes & $\mathrm{PIH}$ & $\begin{array}{l}\text { Moderate CCF/ } \\
\text { IV diuretics, } \\
\text { ß-blocker, ACE-I }\end{array}$ & No & $\begin{array}{l}\text { LVEF } 28 \% \text {, } \\
\text { LVIDd } 5.7 \mathrm{~cm} \text {, } \\
\text { mild-to- } \\
\text { moderate MR }\end{array}$ & $\begin{array}{l}\text { LVEF } 55 \% \text {, } \\
\text { LVIDd } 4.7 \mathrm{~cm} \text {, } \\
\text { trivial MR }\end{array}$ & NYHA I \\
\hline 4 & $\begin{array}{l}34 \text { yrs/ } \\
\text { Chinese/ } \\
\text { G2P1 }\end{array}$ & 6 & No & $\mathrm{PIH}$ & $\begin{array}{l}\text { Moderate CCF/ } \\
\text { IV diuretics, } \\
\beta \text {-blocker, ACE-I }\end{array}$ & No & $\begin{array}{l}\text { LVEF } 30 \% \text {, } \\
\text { LVIDd } 4.85 \mathrm{~cm} \text {, } \\
\text { mild MR }\end{array}$ & $\begin{array}{l}\text { LVEF } 57 \% \text {, } \\
\text { LVIDd } 4.6 \mathrm{~cm} \text {, } \\
\text { no MR }\end{array}$ & NYHA I \\
\hline 5 & $\begin{array}{l}32 \text { yrs/ } \\
\text { Malay/ } \\
\text { G5P5 }\end{array}$ & 9 & Yes & $\mathrm{PIH}$ & $\begin{array}{l}\text { Mild CCF/IV } \\
\text { diuretics, ACE-I }\end{array}$ & No & $\begin{array}{l}\text { LVEF } 33 \% \text {, } \\
\text { LVIDd } 6.2 \mathrm{~cm} \text {, } \\
\text { mild-to- } \\
\text { moderate MR }\end{array}$ & $\begin{array}{l}\text { Lost to } \\
\text { follow-up }\end{array}$ & $\begin{array}{l}\text { Lost to } \\
\text { follow-up }\end{array}$ \\
\hline 6 & $\begin{array}{l}27 \text { yrs/ } \\
\text { Malay/ } \\
\text { G1P1 }\end{array}$ & 7 & Yes & Preeclampsia & $\begin{array}{l}\text { APO/IV diuretics, } \\
\beta \text {-blocker, ACE-I }\end{array}$ & No & $\begin{array}{l}\text { LVEF } 35 \% \text {, } \\
\text { LVIDd } 5.3 \mathrm{~cm} \text {, } \\
\text { trivial MR }\end{array}$ & $\begin{array}{l}\text { Lost to } \\
\text { follow-up }\end{array}$ & $\begin{array}{l}\text { Lost to } \\
\text { follow-up }\end{array}$ \\
\hline 7 & $\begin{array}{l}36 \text { yrs/ } \\
\text { Chinese/ } \\
\text { G1P1 }\end{array}$ & 55 & Yes & NA & $\begin{array}{l}\text { Mild CCF/IV } \\
\text { diuretics, ARB }\end{array}$ & No & $\begin{array}{l}\text { LVEF } 10 \% \text {, } \\
\text { LVIDd } 6.2 \mathrm{~cm} \text {, } \\
\text { moderate MR }\end{array}$ & $\begin{array}{l}\text { LVEF } 40 \% \text {, } \\
\text { LVIDd } 5.6 \mathrm{~cm} \text {, } \\
\text { trivial MR }\end{array}$ & NYHA I \\
\hline 8 & $\begin{array}{l}\text { 31yrs/ } \\
\text { Malay/ } \\
\text { G1P2 }\end{array}$ & 0 & No & NA & $\begin{array}{l}\text { APO requiring } \\
\text { mechanical } \\
\text { ventilation/ } \beta \text { - } \\
\text { blocker, ACE-I }\end{array}$ & Yes & $\begin{array}{l}\text { LVEF } 35 \% \text {, } \\
\text { LVIDd } 5.3 \mathrm{~cm} \text {, } \\
\text { no MR }\end{array}$ & $\begin{array}{l}\text { LVEF } 55 \% \text {, } \\
\text { LVIDd } 5 \mathrm{~cm} \text {, } \\
\text { no MR }\end{array}$ & NYHA I \\
\hline 9 & $\begin{array}{l}31 \text { yrs/ } \\
\text { Malay/ } \\
\text { G2P1 }\end{array}$ & 0 & No & NA & $\begin{array}{l}\text { APO requiring } \\
\text { mechanical } \\
\text { ventilation/ } \beta- \\
\text { blocker, ACE-I }\end{array}$ & Yes & $\begin{array}{l}\text { LVEF } 25 \% \text {, } \\
\text { LVIDd } 4.8 \mathrm{~cm} \text {, } \\
\text { no MR }\end{array}$ & $\begin{array}{l}\text { LVEF 35\%, } \\
\text { LVIDd } 5.5 \mathrm{~cm} \text {, } \\
\text { trivial MR }\end{array}$ & NYHA II \\
\hline 10 & $\begin{array}{l}42 \text { yrs/ } \\
\text { Japanese/ } \\
\text { G1P1 }\end{array}$ & 7 & No & NA & $\begin{array}{l}\text { Moderate CCF/ } \\
\text { IV diuretics, } \\
\beta \text {-blocker, ARB }\end{array}$ & No & $\begin{array}{l}\text { LVEF } 10 \% \text {, } \\
\text { LVIDd } 5.4 \mathrm{~cm} \text {, } \\
\text { mild MR }\end{array}$ & $\begin{array}{l}\text { LVEF } 62 \% \text {, } \\
\text { LVIDd } 4.9 \mathrm{~cm} \text {, } \\
\text { no MR }\end{array}$ & NYHA I \\
\hline 11 & $\begin{array}{l}31 \text { yrs/ } \\
\text { Chinese/ } \\
\text { G1P1 }\end{array}$ & 5 & No & NA & $\begin{array}{l}\text { APO requiring } \\
\text { mechanical } \\
\text { ventilation/ } \\
\text { dobutamine infusion, } \\
\beta \text {-blocker, ACE-I }\end{array}$ & Yes & $\begin{array}{l}\text { LVEF } 30 \% \text {, } \\
\text { LVIDd } 5.4 \mathrm{~cm} \text {, } \\
\text { no MR }\end{array}$ & $\begin{array}{l}\text { LVEF } 65 \% \text {, } \\
\text { LVIDd } 4.4 \mathrm{~cm} \text {, } \\
\text { no MR }\end{array}$ & NYHA I \\
\hline
\end{tabular}

ACE-I: angiotensin-converting enzyme inhibitor; APO: acute pulmonary oedema; ARB: angiotensin II receptor blocker; CCF: congestive cardiac failure; G: gravida; IV: intravenous; LVEF: left ventricular ejection fraction; LVIDd: left ventricular internal diameter in end-diastole; MR: mitral regurgitation; NA: not available; NYHA: New York Heart Association functional classification; P: para; PIH: pregnancy-induced hypertension; PPCM: peripartum cardiomyopathy

One patient had a subsequent pregnancy, which was terminated three months after the diagnosis of cardiomyopathy.

Mean LVEF at diagnosis was $26.9 \% \pm 9.1 \%$ and the mean left ventricular internal diameter in end-diastole (LVIDd) was $5.5 \pm 0.5 \mathrm{~cm}$. Eight patients underwent echocardiographic re-evaluation at the six-month follow-up. Of these, five patients had normal LVEF. Three patients were lost to follow-up. At six months, the mean LVEF was $51.9 \% \pm 10.6 \%$ and LVIDd was 5.1 $\pm 0.6 \mathrm{~cm}$. All patients with at least mild-to-moderate grade mitral regurgitation showed improvement on echocardiography during follow-up. All patients were of NYHA functional class I status on review, except for one patient who was found to be NYHA functional class II.

\section{DISCUSSION}

The incidence of PPCM varies across geographical regions. For instance, it ranges from 1 in 3,000-4,000 live births in the United States, 1 in 1,000 live births in South Africa and 1 in 6,000 live births in Japan. ${ }^{(5,6)}$ In a study from Southern California, Asian populations were found to have the second highest incidence of PPCM, closely following people of African descent. ${ }^{(7)}$ Notwithstanding these wide variations in reported incidence, the real prevalence of PPCM is likely to vary, depending on factors such as accessibility to specialist care as well as the experience of each centre in diagnosing and managing the condition. Moreover, it may be difficult to differentiate PPCM from other conditions associated with heart failure in puerperium, such as 
infectious, toxic or metabolic disorders and underlying valvular or ischaemic heart disease. ${ }^{(8)}$

In our cohort, a majority of the patients presenting with PPCM were ethnically Malay (63.6\%), which translated to 4.62 women with PPCM per 1,000 live births in the Malay population, compared to 0.32 women per 1,000 live births in the Chinese population and 0.84 women per 1,000 live births in women of other races in our series. In spite of the small size of our study population, our findings may hint at the likelihood of PPCM being more prevalent among Malay women. The authors therefore propose that a heightened index of suspicion should be maintained when pregnant Malay women present with symptoms of fluid overload, prompting an early referral for a cardiology assessment.

The risk factors reported for PPCM include women over 30 years of age, multiparity, pregnancies with multiple gestations, African descent, long-term tocolytic therapy (with $\beta$-adrenergic agonists), toxaemia of pregnancy, maternal cocaine abuse and nutritional deficiencies. ${ }^{(5,9,10)} \mathrm{A}$ history of preeclampsia, eclampsia or gestational hypertension is also thought to be associated with PPCM. ${ }^{(11)}$ In contrast to the above reports, we found that $72.7 \%$ of the women in our cohort were in their first pregnancies, with all but one patient having a singleton pregnancy. $45.5 \%$ of the women were smokers, an indication that tobacco smoking may increase the risk of developing PPCM. Equally, 45.5\% of our patients had a history of pregnancy-induced hypertension or preeclampsia. Interestingly, in spite of the increased risk of developing PPCM in women with gestational hypertension, Kamiya et al suggested that hypertensive disorders complicating pregnancy were independently associated with a shorter hospital stay and a higher LVEF on follow-up. ${ }^{(12)}$

Reports have shown that patients who are more critically ill may benefit from intra-aortic balloon pump, left ventricular assist device or heart transplantation, even if they do not respond to earlier treatment. ${ }^{(13)}$ Biteker et al recently demonstrated that intravenous infusion of levosimendan did not improve the outcome in 24 patients with PPCM. ${ }^{(14)}$ There may be potential for the future use of bromocriptine in the treatment of PPCM. Hilfiker-Kleiner et al reported that prolactin, in its antiangiogenic and proapoptotic $16-k D a$ form, is associated with endothelial inflammation, impaired cardiomyocyte metabolism and reduced myocardial contraction, suggesting that oxidative stress, inflammation and prolactin may be interconnected and responsible for initiating PPCM. ${ }^{(15)}$ These authors subsequently conducted a prospective, single-centre, randomised, open-label, proof-of-concept pilot study of 20 women with newly diagnosed PPCM receiving standard care versus standard care plus bromocriptine for eight weeks. ${ }^{(16)}$ In this trial, the addition of bromocriptine to standard heart failure therapy appeared to improve LVEF and a composite clinical outcome of death, NYHA functional class III/IV or LVEF $<35 \%$ at six months in women with acute severe PPCM.

Patients may present with varying degrees of symptoms of heart failure. $54.5 \%$ of our patients presented with mild-to- moderate heart failure and $45.5 \%$ of our patients presented with frank acute pulmonary oedema. Four from the latter group required mechanical ventilation. Only one patient required intravenous dobutamine for inotropic support. The short-term outcome at six months appeared to be excellent in our cohort, as there was no mortality and all patients were successfully treated and discharged well. The treatment of patients with mild-to-moderate heart failure required conventional management with intravenous loop diuretics and $\beta$-blockers when they were out of overt heart failure. ACE-I was initiated after delivery. None of the patients in our cohort received bromocriptine as part of their treatment.

PPCM was associated with dilatation of the left ventricle and depression of LVEF at diagnosis in our series, with improvement seen in both parameters following treatment. In our patients, the mean LVEF was $26.9 \% \pm 9.1 \%$ at diagnosis, which improved to $51.9 \% \pm 10.6 \%$ at six months. Five of eight patients $(62.5 \%)$ who were assessed at six months had LVEF > 50\%. This result is comparable to a previous report by Amos et al, who found improved left ventricular function in two-thirds of their patients, with $45 \%$ of patients returning to a normal ejection fraction (EF $>50 \%$ ). ${ }^{(17)}$ Goland et al recently reported that recovery to LVEF $>50 \%$ at six months was significantly related to the degree of myocardial insult at the time of diagnosis. ${ }^{(18)}$ However, this was not evident in our study group, perhaps owing to its limited sample size.

There were some limitations to our study. Due to the rarity of the condition, we could only recruit a small number of patients for our study; thus, the limited sample size may constrain the statistical significance of our findings. Also, as our cohort was limited to patients from a single tertiary referral centre, whether our findings would be representative of other Asian populations remains uncertain.

In summary, PPCM remains a rare condition but appears to occur more commonly in Malay patients. Smoking and pregnancyinduced hypertension may be significant risk factors associated with the development of PPCM. Short-term outcome was excellent in our cohort. However, the long-term management and outcomes of these patients remain unclear due to the rarity of PPCM. The overall prognosis of PPCM may improve with the development of newer treatment modalities such as bromocriptine, as well as with increased awareness, prompt detection and earlier initiation of appropriate therapy for at-risk women, especially among high-risk groups. Collaborative studies with other tertiary centres would help to better understand the condition.

\section{REFERENCES}

1. O'Connell JB, Costanzo-Nordin MR, Subramanian R, et al. Peripartum cardiomyopathy: clinical, hemodynamic, histologic and prognostic characteristics. J Am Coll Cardiol 1986; 8:52-6.

2. Felker GM, Jaeger CJ, Klodas E, et al. Myocarditis and long-term survival in peripartum cardiomyopathy. Am Heart J 2000; 140:785-91.

3. Midei MG, DeMent SH, Feldman AM, Hutchins GM, Baughman KL. Peripartum myocarditis and cardiomyopathy. Circulation 1990; 81:922-8.

4. Pearson G, Veille J, Rahimtoola S, et al. Peripartum cardiomyopathy: National Heart, Lung and Blood Institute and office of rare diseases 
(National Institute of Health) workshop recommendations and review. JAMA 2000; 283:1183-8.

5. Sliwa K, Fett J, Elkayam U. Peripartum cardiomyopathy. Lancet 2006; 368:687-93.

6. Mayosi BM. Contemporary trends in the epidemiology and management of cardiomyopathy and pericarditis in sub-Saharan Africa. Heart 2007; 93:1176-83.

7. Brar SS, Khan SS, Sandhu GK, et al. Incidence, mortality, and racial differences in peripartum cardiomyopathy. Am J Cardiol 2007; 100:302-4.

8. Lok SI, Kirkels JH, Klöpping C, Doevendans PA, de Jonge N. Peripartum cardiomyopathy: the need for a national database. Neth Heart J 2011; 19:126-33.

9. Demakis JG, Rahimtoola SH. Peripartum cardiomyopathy. Circulation 1971; 44:964-8.

10. Selle T, Renger I, Labidi S, Bultmann I, Hilfiker-Kleiner D. Reviewing peripartum cardiomyopathy: current state of knowledge. Future Cardiol 2009; 5:175-89.

11. Fett JD, Christie LG, Carraway RD, Murphy JG. Five-year prospective study of the incidence and prognosis of peripartum cardiomyopathy at a single institution. Mayo Clin Proc 2005; 80:1602-6.

12. Kamiya CA, Kitakaze M, Ishibashi-Ueda $H$, et al. Different characteristics of peripartum cardiomyopathy between patients complicated with and without hypertensive disorders. -Results from the Japanese Nationwide survey of peripartum cardiomyopathy. Circ J 2011; 75:1975-81.

13. Gevaert S, Van Belleghem Y, Bouchez S, et al. Acute and critically ill peripartum cardiomyopathy and 'bridge to' therapeutic options: a single center experience with intra-aortic balloon pump, extracorporeal membrane oxygenation and continuous-flow left ventricular assist devices. Crit Care 2011; 15:R93.

14. Biteker M, Duran NE, Kaya $H$, et al. Effect of levosimendan and predictors of recovery in patients with peripartum cardiomyopathy, a randomized clinical trial. Clin Res Cardiol 2011; 100:571-7.

15. Hilfiker-Kleiner D, Kaminski K, Podewski E, et al. A cathepsin D-cleaved $16 \mathrm{kDa}$ form of prolactin mediates postpartum cardiomyopathy. Cell 2007; 128:589-600.

16. Sliwa K, Blauwet L, Tibazarwa K, et al. Evaluation of bromocriptine in the treatment of acute severe peripartum cardiomyopathy. A proof-of-concept pilot study. Circulation 2010; 121:1465-73.

17. Amos AM, Jaber W, Russell SD. Improved outcome in peripartum cardiomyopathy with contemporary. Am Heart J 2006; 152:509-13.

18. Goland S, Bitar F, Modi K, et al. Evaluation of the clinical relevance of baseline left ventricular ejection fraction as a predictor of recovery or persistence of severe dysfunction in women in the United States with peripartum cardiomyopathy. J Card Fail 2011; 17:426-30.

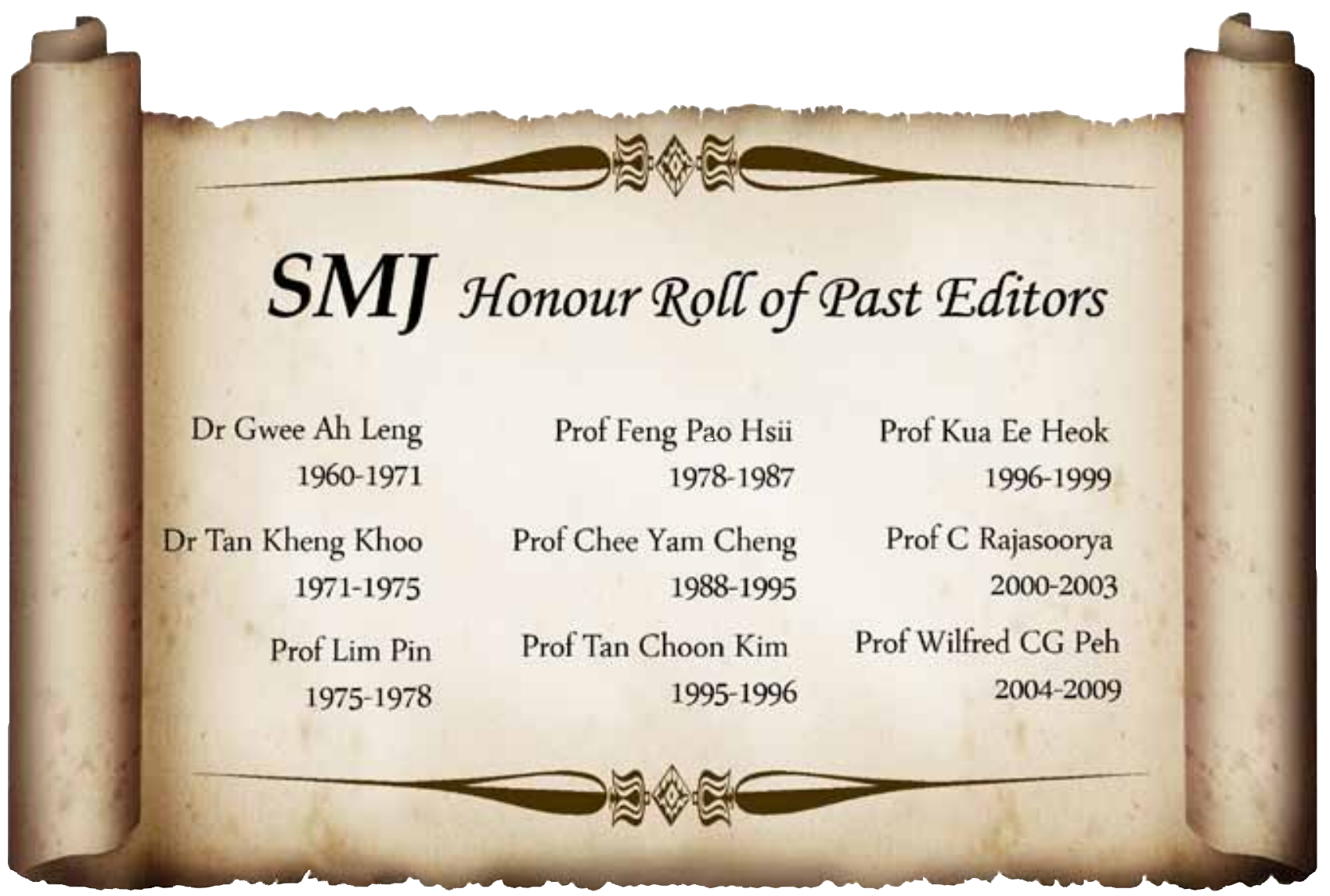

